\title{
Research on College English Teaching Patterns in Application-Oriented Universities Based on ESP
}

\author{
Lei Wang \\ School of Liberal Arts \\ Xi'an International University \\ Xi'an City, Shaanxi Province, China
}

\begin{abstract}
English for Specific Purposes (ESP) is a special English teaching and education field which derives from the 1960s. As it can well illustrate the instrumental aspect, highlight the practical values, and stresses the differences among individual learner in college English courses, it has always been popular in college English teaching in China. With the booming of social economy, college English teaching has encountered many opportunities and challenges in the new era, and ESP theories and practice can help to solve the problems and meet the learning demands of college students, especially those from application-oriented universities. Therefore, this paper begins with the analysis of current situation of college English ESP courses in application-oriented institutions, and intends to propose feasible methods to improve the efficiency and effectiveness of ESP teaching in these universities. With transformation of teaching ideology, scientific design for ESP courses, training of ESP teachers and enriched ESP classroom teaching, students are expected to equip themselves with the knowledge and skills needed for their future career and development.
\end{abstract}

Keywords-college English teaching; ESP courses; teaching ideology and methodology; teacher training; classroom teaching; practice

\section{INTRODUCTION}

In order to adapt to the talent cultivation requirements deriving for the economic structure adjustment and industry upgrading, the Ministry of Education in China issued a document entitled Opinions on Guiding some Local Undergraduate Colleges to Transform into Application-Oriented Institutions. The document suggests local universities focus on serving local economy, integrating industry and education, and cultivating application-oriented talents. In this case, a large number of local universities across the country begin to answer to call of the government to construct application-oriented institutions [1]. This transformation has put forward higher requirements for college English course, which means these courses have to stress more on how to apply language knowledge to practice instead of training language skills.

Actually, there is obvious imbalance between college English teaching and English practice in real career settings. As a result, college English teaching has to invest more in helping students acquiring practical skills like how to communicate with foreign partners in business settings, how to write application letters for careers and further studies, how to catch English radio and video programs, and so on. The latest College English Curriculum Requirements has divided College English into three categories: General English, English for Specific Purposes (ESP) and Inter-Cultural Communications [2]. ESP highlights the instrumental functions of English and design courses to narrow the gap between class-room English and language use and application, which significantly promotes the effectiveness, practicability and usefulness of college English teaching [3]. The content of the whole college English course system is widened.

\section{CuRRENT Situation OF COLlEGE ENGLISH ESP COURSES IN APPLICATION-ORIENTED INSTITUTIONS}

The development of globalization has placed English in an increasingly important position. Not only college students and teachers strive to improve English learning and teaching, but also working staff take advantage of the internet resources to boost their English proficiency in the competitive career scenarios. In the fields of culture and education, international students and exchange students have taken an ever-growing proportion, which also demonstrates the importance of English. However, traditional English teaching and learning's stress on general English doesn't conform to users' real needs in practical settings. For college graduates, what they need most is still the use of English in their own fields. Considering this, more and more application-oriented institutions tend to add ESP courses to their college English curriculum. Although certain progress has been made, some problems still exist in college English teaching and learning. The major problems are listed as follows:

\section{A. The Purpose of ESP is Unclear}

In theory, the purpose of ESP is to improve college students practical English to prepare them for future careers. However, highly influenced by exam-oriented teaching pattern in secondary school, most higher-learning institutions still continue "reading and writing first, listening and speaking second" pattern, which brings about the phenomenon that students get high scores in exams, but they can neither speak to foreigners nor understand English radio or TV programs. ${ }^{[4]}$ This is what employers complain most about our college English teaching.

For some universities, they just replace traditional college English courses with ESP courses, and design and carry out 
ESP teaching in the traditional way, which ignores the professionalism of ESP. And for most students, they have little idea on the significance of ESP courses, and have little motivation to choose and learn them. With more practical skills in ESP courses, students will show more interest in learning and gain more for future application.

\section{B. ESP Textbooks and Reference Books are Scarce.}

ESP research and teaching in China just started from 1990s, and till today, we only have limited materials. The current textbooks are not of high quality, with content design similar to traditional textbooks focusing more on reading and writing, which goes against ESP teaching target [5]. Moreover, current textbooks and reference books can neither meet students' needs nor catch up with the booming social and economic development. As a result, the lack of high-quality teaching materials results in students' disinterest in learning the course and teachers' low efficiency in teaching the course. The situation must be changed either by introducing high-quality reference books abroad or compiling our own textbooks based on China's social and economic demands.

\section{ESP Teachers' Teaching Abilities are to be Improved.}

With increasing number of students entering college, there is an imbalance between the numbers of students and teachers. Due to the lack of college English teachers, most teachers still follow the teacher-centered patter with inadequate interaction and output practice. Although some universities have designed several ESP courses, teachers still use the traditional teaching methods, focusing more on language rather than the content of the course.

More importantly, ESP courses belong to comprehensive disciplines, which not only requires teachers' high proficiency in English, but also profound knowledge in certain fields. However, current ESP teachers are mainly English language teachers in their career and lack the knowledge and experience in scientific fields, which leads to difficulty in ESP teaching. In this case, when they teach ESP courses, they still follow the language teaching mode, stressing vocabulary, reading skills and writing exercise. As a result, the effectiveness of ESP courses are much weakened because of old-fashioned teaching ideology and methodology.

\section{WAYS TO IMPROVE ESP TEACHING AND LEARNING IN APPLICATION-ORIENTED INSTITUTIONS}

\section{A. Transformation of Teaching Ideology}

Application-oriented universities are suggested to cultivate qualitied professionals with certain theoretical background, applied and technological skills to cater to local social and economic development. Therefore, in order to help students to acquire applied skills in ESP courses, the teaching ideology has to be changed to be in line with the requirement and development of the course [6].

\section{1) Transformation from "Exam-Oriented" to} "Application-Oriented"

In college English teaching practice, many universities still take College English Test (CET) as the most important standard of language proficiency. In order to pass the test, both teachers and students invest most of their energy to enlarge their vocabulary and testing skills, ignoring the cultivation of English application abilities. However, the purpose of English learning is supposed to master practical skills instead of solely focusing on language and cultural knowledge. Therefore, in college English, more high-quality ESP courses are supposed to be designed to promote students' practical abilities in real application scenarios.

2) Transformation from "One-way Input" to "Two-Way Interaction"

In recent years, with increasing investment in hardware construction in Chinese universities, teaching conditions have been much improved. The popularity of internet-based classrooms has provided an effective platform for teacher-student interaction. College English teaching department takes advantages of the situation and designs relevant ESP courses, like Business English Listening and Speaking, English for Foreign Trade, English for Material Science and so on. English learning and discipline research has well been integrated and much practice and interaction has been carried out; the effectiveness of English courses has upgraded to a new stage with enormous opportunities to practice students' output and applied skills.

\section{B. Scientific Design of ESP courses}

ESP can be served as a bridge to integrate language and major. More emphasis should be placed on the design of ESP courses: on the one hand, they should become an indispensable and compulsory component of college English courses instead of elective courses; on the other hand, ESP courses have to meet the demands of students' career development and requirements from the job market [4].

The design of ESP courses have to be based on students' real learning needs. In teaching, the course schedule, content, and teaching methods can be adjusted. At the same time, the cooperation between ESP teachers and discipline teachers can be strengthened to enrich the content of the course, improve the integration of relevant courses and help students understand the usefulness and importance of ESP course for their career development.

Therefore, application-oriented universities are supposed to develop a scientific college English teaching system that includes both language courses and ESP courses to make the best of resources. The system follows "general English + career English + discipline English" pattern to meet students' demands in different stages.

For general language courses, they can focus on the traditional language skills like listening, speaking, writing, reading and translation; for career English courses, they can develop students applied abilities for future jobs like English for international trade and English for intercultural communication; for discipline English courses, they can cultivate students interest and ability to further their learning in their fields, like law, economy, engineering, chemistry and so forth. With this full system of English language learning, students' language abilities will be strengthened and their application skills will be improved.

In the first years, students are encouraged to select general English courses to lay a solid language foundation for further 
learning. In the second year, students can select career English courses based on their career planning; at the same time, if students are ambitious enough to pursue postgraduate studies in future, they can also add discipline English to their course list. In this way, students' individual learning demands have been met and their future development has been fully considered. In this course system, the objective of the college English course is clear; both teachers and students know what to learn and how to learn English in college.

\section{Training of ESP Teachers}

Teacher training plays an important role in quality control of teaching affairs for all levels of universities. Without a quality faculty team, the effectiveness of a course can never be guaranteed. For application-oriented universities, they can construct a high-quality ESP teaching faculty with comprehensive knowledge structure from the following aspects.

In the first place, application-oriented universities can employ new international talents in teaching to construct a universal teaching group. And for the group members, they can put what they have learned abroad into Chinese classroom settings when they implement full-English ESP teaching. In the meantime, teachers with domestic education background can also learn from them.

In the second place, universities have to invest more in training the current teachers. In the new era, an English teacher is not only an expert in language teaching, but also should catch up with the latest advances in one or even several scientific fields. Thus, in summer or winter vocations, universities can invite ESP experts outside to give lectures to re-train these teachers. At the same time, teachers can also participate in national or international conferences and visit relevant businesses or enterprises to acquire more knowledge and practice for their course.

In the third place, an assessment mechanism concerning teacher training and teaching effectiveness can be designed to ensure that all the efforts on faculty development of ESP teachers are worthwhile. The focus of the assessment is about the course instead of only teachers. In the process, teachers will try to improve their teaching from a third person's perspective. With these measures taken, the quality of ESP teachers will be greatly improved, and the objective of cultivating qualified college graduates with competence in English in working settings will be achieved smoothly.

\section{Enriching ESP Classroom Teaching}

The classroom serves as the place both for students to learn knowledge and to acquire learning methods. Teachers are supposed to equip themselves with management abilities to motivate students to make the best of their time in college. On the basis of fully understanding of students' learning needs, teachers can constantly optimize their course design to guarantee that students can apply what they have learned in college to real career settings in future [7]. The dynamic interaction among all course elements will greatly promote and enrich the content of ESP classroom teaching.

ESP classroom teaching is basically student-centered to trigger students' motivation. In the teaching process, teachers design and organize various interactive activities to visualize the idea of "learning by doing". Meanwhile, all sorts of teaching methods, like task-based teaching, project-based instruction and poster presentation can be fully utilized to improve students' learning efficiency and quality.

The classroom learning and teaching can also be extended to daily practice out of classroom or even out of campus. With the help of school authorities, teachers can organize their students to visit businesses in the field out of campus to narrow the gap between the book knowledge and real application. Only in this way will students know that "what they are learning in classroom can be applied to solve real problems in reality"; the values of knowledge and skills are well demonstrated in authentic settings.

\section{CONCLUSION}

To sum up, in order to cultivate students with qualitied applied abilities to contribute to local social and economic development upon their graduation, the college English course has to consider how to teach applied language and discipline knowledge and skills in college. The design and construction of ESP courses has provided a solution to the issue. With the transformation of teaching ideology, scientific design, sufficient faculty training, and enriched classroom teaching and off-campus practice, students' practical English abilities will be remarkably improved to meet the demands of the competitive job market. Currently, many application-oriented colleges and universities have already designed ESP courses based on the situation of their institutions and made some progress. With all the efforts made in reforming college English teaching and research, college graduates will better adapt to what is required for their practical and applied language skills after finishing their college.

\section{REFERENCES}

[1] "Opinions on Guiding some Local Undergraduate Colleges to Transform into Application-Oriented Institutions," http://www.moe.gov.cn/srcsite/A03/moe_1892/moe_630/201511/t20151 113_218942.html

[2] Higher Education department, Ministry of Education, "College English Curriculum Requirements", Beijing: Foreign Language Teaching and Research Press, 2007, pp. 32.

[3] Rod Ellis, "Understanding Second Language Acquisition", Shanghai: Shanghai Foreign Language Education Press, 1999.

[4] Wu Dan, "Exploration of English Teaching Transformation from the Perspective of Building Application-Oriented Universities," Journal of Guangxi Education College, 2018 (1), pp.138-140.

[5] Gu Yunfei, "Research on College English ESP Courses in Application-Oriented Universities", Education Modernization, 2019 (2), pp. 139-141.

[6] Tom Hutchinson \& Alan Waters, "English for Specific Purposes," Shanghai: Shanghai Foreign Language Education Press, 2002.

[7] Zhou Wenli, Exploration of New Patterns of English Teaching in Higher Education, Foreign Languages and Their Teaching, 2013 (05): 10-13 